\title{
A Novel Mass Spectrometric Method to Distinguish Isobaric Monosaccharides that are Phosphorylated or Sulfated Using Ion-Pairing Reagents
}

\author{
Ying Zhang, Eden P. Go, Hui Jiang, and Heather Desaire \\ Department of Chemistry, University of Kansas, Lawrence, Kansas, USA
}

Phosphorylation and sulfation are two important biological modifications present in carbohydrates, proteins, and glycoproteins. Typically, sulfation and phosphorylation cause different biological responses, so differentiating these two functional groups is important for understanding structure/function relationships in proteins, carbohydrates, and metabolites. Since phosphorylated and sulfated compounds are isobaric, their discrimination is not possible in routinely utilized mass spectrometers. Thus, a novel mass spectrometric method to distinguish them has been developed. Herein, we utilize basic peptides as ion-pairing reagents to complex to phosphorylated and sulfated carbohydrates via noncovalent interactions. By performing ESI-MS/MS on the ion-pair complexes, the isobaric compounds can be distinguished. This is the first study demonstrating that ion-pairing can be used for the detection of phosphorylated compounds and the first study to use ion-pairing in conjunction with MS/MS to obtain structural information about the analytes. (J Am Soc Mass Spectrom 2005, 16, 1827-1839) (c) 2005 American Society for Mass Spectrometry

$\mathrm{P}$ hosphorylation and sulfation are functionally significant biological modifications commonly found in metabolites, carbohydrates, proteins, and glycoproteins. Phosphorylation is linked to signal transduction, gene expression, cell cycle, cytoskeletal regulation, and apoptosis [1-8]. In particular, phosphorylated carbohydrates are integral components of nucleic acids [1, 5], oligosaccharides [1, 5], glycopeptides [2-4, 6], and glycoproteins [2-4]. They are also involved in glycolysis processes in the extracellular matrix $[7,8]$. Sulfation effects protein recognition and helps facilitate clearance of proteins and metabolites from the body [9-14]. Specifically, sulfated carbohydrates represent a class of biologically active and pharmaceutically important molecules [10]. They are essential in neuropathology and are used as therapeutic agents [9]. Because phosphorylation and sulfation have been linked to different biological functions, differentiating these structures is essential for understanding structure/function relationships in proteins, carbohydrates, and metabolites.

Numerous studies [1-4, 6, 7, 9-18] have been utilized to characterize phosphorylation and sulfation. These methods indicate that selective and sen-

Published online September 26, 2005

Address reprint requests to Dr. H. Desaire, Department of Chemistry, University of Kansas, 1251 Wescoe Hall Drive, Lawrence, KS 66045, USA.

E-mail: hdesaire@ku.edu sitive detection of phosphorylated and sulfated compounds in complex matrices is paramount. Radiolabeling $[3,6,11-14]$ is one of the commonly used methods to identify phosphorylated and sulfated carbohydrates with good specificity. While this method is hazardous and time-consuming, phosphorylated or sulfated species can be selectively discriminated in the presence of many other compounds in the matrix, using radiolabeling.

Mass spectrometry, which is highly selective and sensitive, could possibly provide information about phosphorylation and sulfation without the need for radiolabeling [3, 15-17]. Recent MS experiments to identify phosphorylated compounds include exact mass differentiation [2] and discrimination using ionmolecule reactions [1] by using Fourier transform ion cyclotron resonance mass spectrometry (FTICR-MS). While these two methods are useful in differentiating the presence of phosphorylated and sulfated compounds, only a few groups have access to these sophisticated instruments. Thus, developing the mass spectrometric methods on more readily available instruments will benefit investigators who are interested in this field.

Herein, we utilize basic peptides $[9,19-23]$ as ionpairing reagents to complex to phosphorylated or sulfated carbohydrates via noncovalent interactions [9, 19-23] and perform MS/MS experiments on each complex to obtain the structural information. This is the 


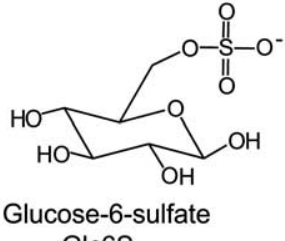

Glc6S

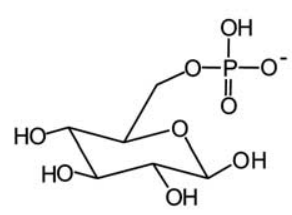

Glucose-6-phosphate Glc6P

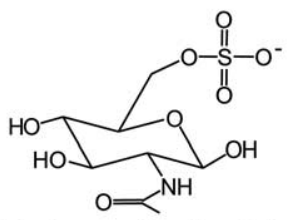

$\mathrm{N}$-acetyl-glucosamine-6-sulfate $\mathrm{N}$-acetyl-glucosamine-6-phosphate GICNAc6S

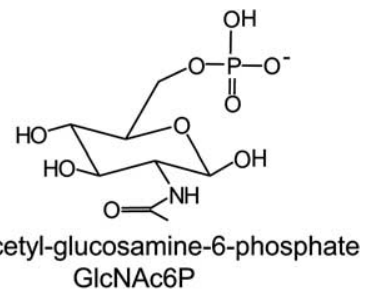

GlcNAc6P

Scheme 1

same ion-pairing technique employed in MALDI and ESI that is used to enhance the signal of sulfated carbohydrates $[19,20]$. Since both phosphate and sulfate are highly acidic compounds with different proton affinities, differences in their chemical reactivities with the ion-pairing reagents may be used to distinguish their structures by MS/MS experiments. This is the first study to illustrate that ion-pairing can be used in conjunction with MS/MS to differentiate isobaric phosphorylated and sulfated compounds. In addition to its application to simple carbohydrates, this method is also potentially applicable in identifying phosphorylation and sulfation in glycosaminoglycans and glycoproteins in biological samples.

This work complements other mass spectrometric studies that have discriminated phosphorylation from sulfation using FTICR-MS [1, 2], and most recently MALDI-MS, in which the differentiation was accomplished by monitoring the differences in the ionization behavior between the two functional groups [24]. In addition to discriminating these isobars, ion pairing has the added advantage of simultaneously enhancing the mass spectral signal of these acidic groups, even when they are present in complex mixtures of other compounds [20].

\section{Experimental}

\section{Chemicals and Materials}

All of the phosphorylated and sulfated monosaccharides and peptides were purchased from SigmaAldrich (St. Louis, MO), except the three basic peptides Arg-Arg-Arg (R3), Arg-Ser-Lys (RSK), and ArgGly-Lys (RGK). These three small peptides were synthesized at the University of Kansas Biological Research Service Laboratory using solid-phase peptide synthesis. All chemicals were used without further purification and all solvents were HPLC grade.

\section{Sample Preparation}

All of the compounds, including basic peptides, were dissolved in a minimal amount of HPLC grade water. Peptide stock solutions were further diluted with methanol:water (MeOH: $\mathrm{H}_{2} \mathrm{O}$ ) mixture (1:1) containing 0.5\% acetic acid, to a final concentration of $2 \mathrm{mM}$. All phosphorylated and sulfated monosaccharides were diluted to $1 \mathrm{mM}$. Before MS analysis, ion-pair com- plexes were formed by combining $5 \mu \mathrm{L}$ of basic peptide solution and $5 \mu \mathrm{L}$ of monosaccharides solution. The mixture was thoroughly mixed and 1 to $2 \mu \mathrm{L}$ were directly injected into the mass spectrometer.

\section{Mass Spectrometry}

A Surveyor MS-pump (Thermo, San Jose, CA) was used to deliver the mobile phase of $\mathrm{MeOH}: \mathrm{H}_{2} \mathrm{O}(1: 1)$ containing $0.5 \%$ acetic acid at a flow rate of $20 \mu \mathrm{L} / \mathrm{min}$. 1 to 2 $\mu \mathrm{L}$ of samples were directly injected into mass spectrometer. All samples were analyzed on a ThermoFinnigan LCQ Advantage quadrupole ion trap mass spectrometer (ThermoFinnigan, San Jose, CA). Electrospray ionization in both positive and negative ion mode was achieved by using a spray voltage of $\sim 4.0$ $\mathrm{kV}$. Nitrogen was used as a nebulizing gas, at a pressure of 20 psi. A capillary temperature of $200-230{ }^{\circ} \mathrm{C}$ was maintained. Ion-pairing experiments were performed in positive ion mode, and MS data of the native carbohydrates were recorded in negative ion mode.

Collision-induced dissociation (CID) was performed to obtain structural information. Specifically, doubly charged precursor ions were activated for $30 \mathrm{~ms}$ with $20 \%$ normalized collision energy. A $q_{z}$ value of 0.25 and an isolation width of $3 \mathrm{Da}$ were used. The singly charged precursor ions were activated with 15\% normalized collision energy.

\section{Results and Discussion}

\section{MS Data for Isobaric Monosaccharides Without Ion-Pairing}

To demonstrate the effectiveness of the ion-pairing technique in differentiating between phosphorylated and sulfated compounds, two sets of isobaric phosphorylated and sulfated monosaccharides were chosen as $\operatorname{model}^{\circ} \operatorname{compounds}^{\circ}\left(\right.$ Scheme $\left.^{\circ} 1\right)$.

In the first set of experiments, the fragmentation characteristics of the isobaric monosaccharides without ion-pairing were examined. MS/MS data revealed that the two sets of isobaric monosaccharides, glucose-6phosphate (Glc6P)/glucose-6-sulfate (Glc6S), and N-acetyl-glucosamine-6-phosphate (GlcNAc6P)/ $\mathrm{N}$-acetyl-glucosamine-6-sulfate (GlcNAc6S) produce identical ${ }^{\circ} \mathrm{MS} / \mathrm{MS}^{\circ} \mathrm{data}^{\circ}\left(\right.$ Figure $\left.^{\circ} 1 \mathrm{a}-\mathrm{d}\right) .{ }^{\circ} \mathrm{As}^{\circ} \mathrm{a}^{\circ}$ result, ${ }^{\circ}$ these 


\section{(a) Glc6P}

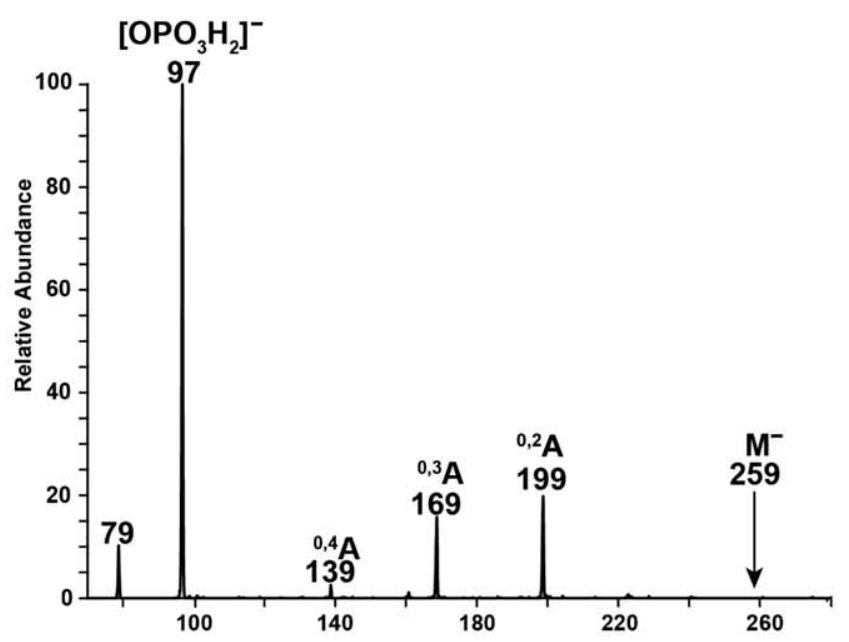

(b) GIc6S

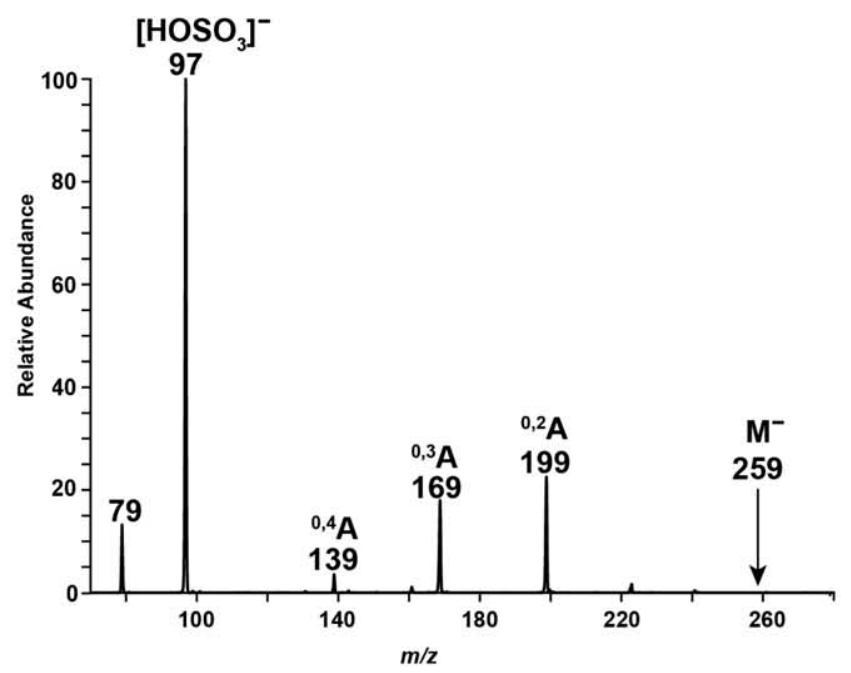

(c) GIcNAc6P

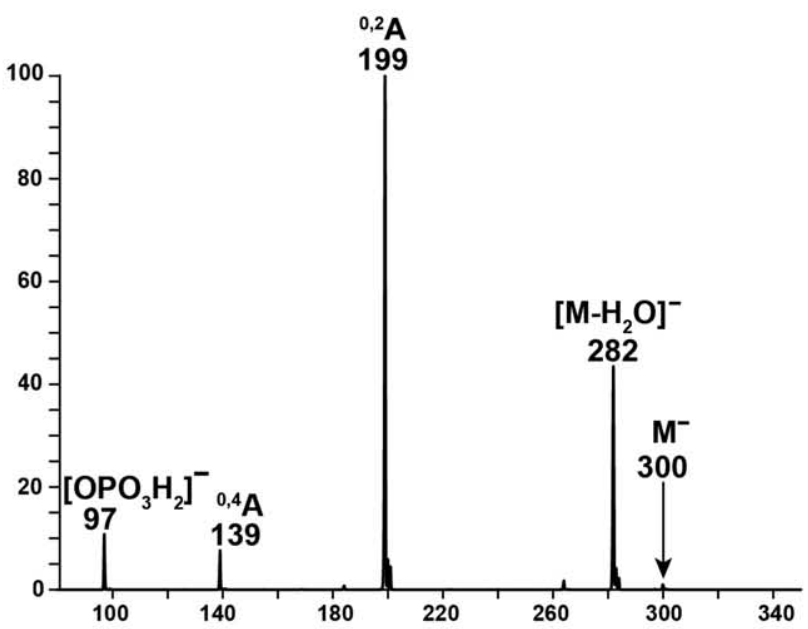

Figure 1. (-)ESI-MS/MS data for phosphorylated and sulfated carbohydrates. Isobaric pairs provide identical spectra. Each product ion is labeled: (a) glucose-6-phosphate (Glc6P), (b) glucose-6-sulfate (Glc6S), (c) $\mathrm{N}$-acetyl-glucosamine-6-phosphate (GlcNAc6P), and (d) N-acetyl-glucosamine-6-sulfate (GlcNAc6S).

isobaric monosaccharides cannot be distinguished using standard MS/MS methods.

\section{Ion-Pairing for Sulfated and Phosphorylated Carbohydrates}

$\mathrm{To}^{\circ}$ overcome $^{\circ}$ this ${ }^{\circ}$ problem, ${ }^{\circ}$ ion-pairing ${ }^{\circ}\left[9^{\circ}, 19{ }^{\circ} 23\right]^{\circ}$ was employed for the analysis. Ten different basic peptides, Lys-Lys (K2), Lys-Lys-Lys (K3), Lys-Tyr-Lys (KYK), ArgSer-Lys (RSK), Arg-Gly-Lys (RGK), Arg-Arg-Arg (R3), Lys-Lys-Lys-Lys (K4), Arg-Lys-Arg-Ser-Arg-Lys-Glu (P1), Ser-Arg-Val-Ser-Arg-Arg-Ser-Arg (P2), Lys-Arg-Thr-LeuArg-Arg (P3), were evaluated for their potential to form ion-pairing complexes with the acidic carbohydrates and facilitate their discrimination in MS/MS experiments. These peptides were complexed with the isobaric carbohydrates ${ }^{\circ}{ }^{\circ}{ }^{\circ}$ cheme $^{\circ} 1$. $^{\circ}$ Typical $^{\circ} \mathrm{MS}^{\circ}$ data $^{\circ}$ of ${ }^{\circ}$ the ${ }^{\circ}$ carbohydrate and peptide ion-pairs depict the formation of abundant ion-pair complexes. An example of the carbohydrate: peptide complex between the phosphorylated carbohydrate, ${ }^{\circ} \mathrm{Glc} 6 \mathrm{P}$, ${ }^{\circ}$ and ${ }^{\circ}$ the ${ }^{\circ}$ tripeptide, ${ }^{\circ} \mathrm{R} 3{ }^{\circ}{ }^{\circ}{ }^{\circ}{ }^{\circ}$ shown ${ }^{\circ}$ in ${ }^{\circ}$ Figure 2 . Since the basic side-chain of the peptide is easily protonated under the conditions used in this analysis, both doubly and singly charged ion-pair complexes are formed in the spectrum. This is the first example that demonstrates ion-pairing, which is typically used to facilitate MS detection ${ }^{\circ}$ of $^{\circ}$ sulfated $^{\circ}$ compounds $^{\circ}\left[9,{ }^{\circ} 20,{ }^{\circ} 21\right],,^{\circ} \mathrm{can}^{\circ}$ also ${ }^{\circ}$ be used for phosphorylated species. 


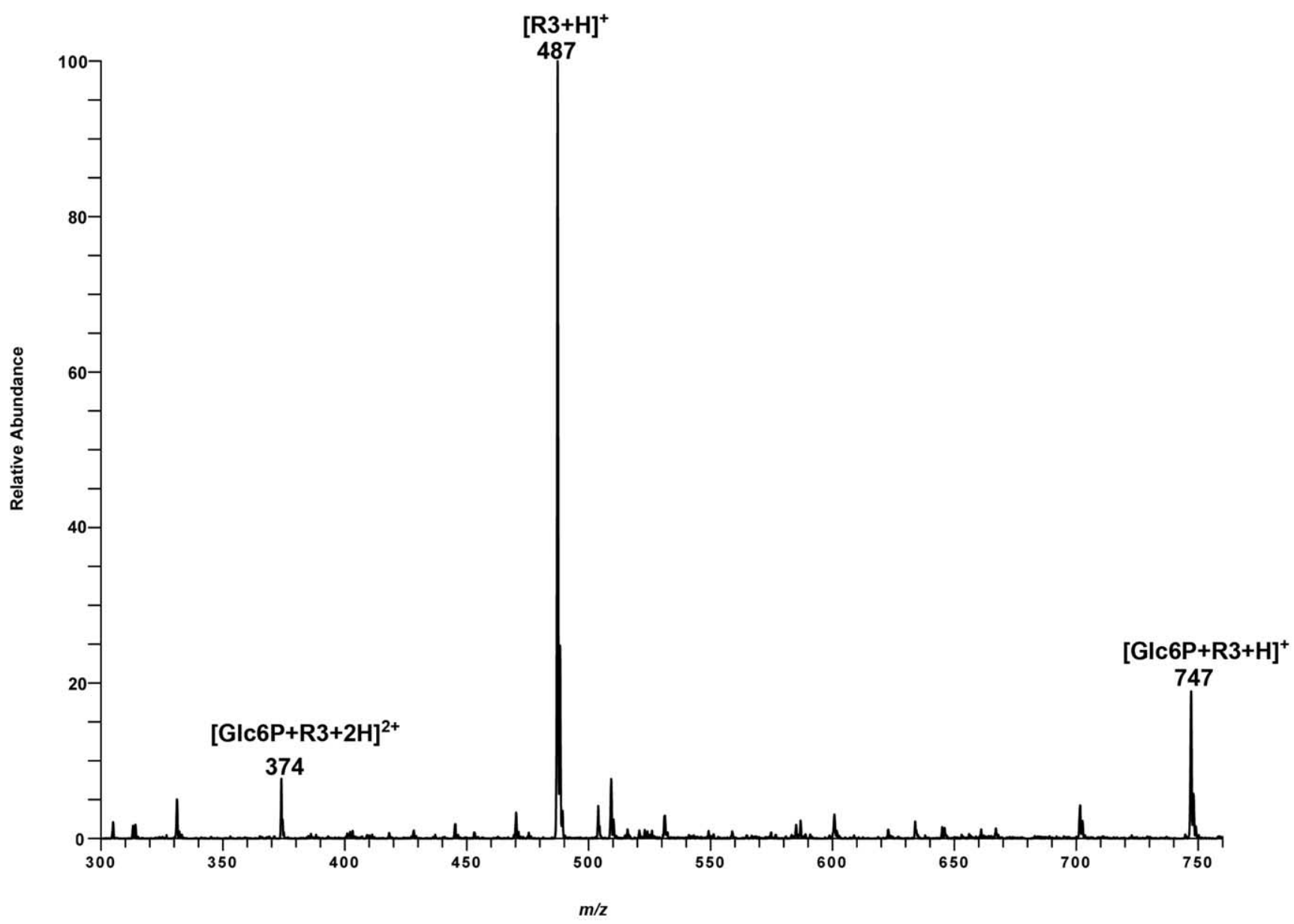

Figure 2. (+)ESI-MS data for the phosphorylated carbohydrate glucose-6-phosphate (Glc6P) after the addition of the ion-pairing reagent Arg-Arg-Arg (R3). The spectrum shows the two ion-pairs, $[\mathrm{Glc} 6 \mathrm{P}+\mathrm{R} 3+2 \mathrm{H}]^{2+}$ and $[\mathrm{Glc} 6 \mathrm{P}+\mathrm{R} 3+\mathrm{H}]^{+}$.

Structural information on each carbohydrate:peptide complex was obtained from MS/MS experiments. The

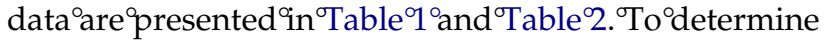
which peptide could be used in the differentiation study, the fragmentation pattern of each singly and doubly charged ion-pair complex was compared. The most effective ion-pairing reagents were identified as those that could discriminate both sets of isobaric monosaccharides, ${ }^{\circ}$ in $^{\circ} \mathrm{Scheme}^{\circ} 1 .^{\circ} \mathrm{A}^{\circ}$ summary ${ }^{\circ}$ of $^{\circ}$ all $^{\circ}$ the MS $/$ MS $^{\circ}$ data $^{\circ}$ is $^{\circ}$ in $^{\circ}$ Tables $^{\circ} 1^{\circ}$ and $^{\circ} 2 .^{\circ}$ Peptides $^{\circ}$ that ${ }^{\circ}$ pro- $^{-}$ duced unique product ions for one of the isobaric compounds were deemed "useful", because they could discriminate the isobars by MS/MS.

Table ${ }^{\circ}$ shows ${ }^{\circ}$ data ${ }^{\circ}$ for ${ }^{\circ}$ the ${ }^{\circ}$ ingly ${ }^{\circ}$ charged $^{\circ}$ complexes. Several peptides were ruled out as potentially useful ion-pairing candidates because their MS/MS data were identical for both sets of the isobaric carbohydrate: peptide ion-pairs. In fact, only the three peptides, R3, $\mathrm{K} 3$, ${ }^{\circ}$ and ${ }^{\circ} \mathrm{KYK}$, in ${ }^{\circ} \mathrm{Table}^{\circ} 1,{ }^{\circ}$ could $^{\circ} \mathrm{be}^{\circ}$ used $^{\circ}$ to $^{\circ}$ differentiate all the isobars in this study. The same comparison was made ${ }^{\circ}$ for ${ }^{\circ}$ the ${ }^{\circ}$ doubly $^{\circ}$ charged $^{\circ}$ complexes in Table 2 . The peptides ${ }^{\circ} \mathrm{P} 1,{ }^{\circ} \mathrm{P} 2,{ }^{\circ} \mathrm{P} 3,{ }^{\circ}$ and ${ }^{\circ} \mathrm{K} 3{ }^{\circ}$ in $^{\circ}$ Table $^{\circ} 2^{\circ}$ were ${ }^{\circ}$ useful ${ }^{\circ}$ for discriminating the doubly charged isobaric complexes.
Combining the results from both tables indicate that $\mathrm{K} 3$ can be used to differentiate isobaric carbohydrates, in a charge-state independent fashion. The ion-pair complexes can have different charge states (singly and doubly charge) in ESI. Thus, it would be beneficial if this method could be used to discriminate the ion-pairs in both charge states. In addition, being able to differentiate the isobars using two different charge states is useful because it provides two methods of confirming the functional groups' assignment. To better understand why these isobaric complexes have different MS/MS data, the spectra for the phosphorylated and sulfated ion-pairs are compared.

\section{Comparison of the MS/MS Data: Doubly Charged Complexes with K3}

The MS/MS data of the doubly charged ion-pairs of glucose-6-phosphate [Glc6P $+\mathrm{K} 3+2 \mathrm{H}]^{2+}$ and glucose6-sulfate $\left[\mathrm{Glc}^{\circ} 6 \mathrm{~S}^{\circ}+\mathrm{K}^{\circ}+{ }^{\circ} \mathrm{H}\right]^{2+}{ }^{\circ}$ are shown in Figure $3 \mathrm{a}^{\circ}$ and b. ${ }^{\circ}$ The ${ }^{\circ}$ product ${ }^{\circ}$ ions ${ }^{\circ}$ of ${ }^{\circ}$ the ${ }^{\circ}$ ion-pair ${ }^{\circ}$ complex, ${ }^{\circ}\left[\mathrm{Glc}^{\circ} \mathrm{P}^{\circ}+{ }^{\circ} \mathrm{K} 3\right.$ $\left.+{ }^{2} \mathrm{H}\right]^{2+}{ }^{\circ}$ in Figure 3 a include the singly charged $\mathrm{K} 3$ at $\mathrm{m} / \mathrm{z}$ 


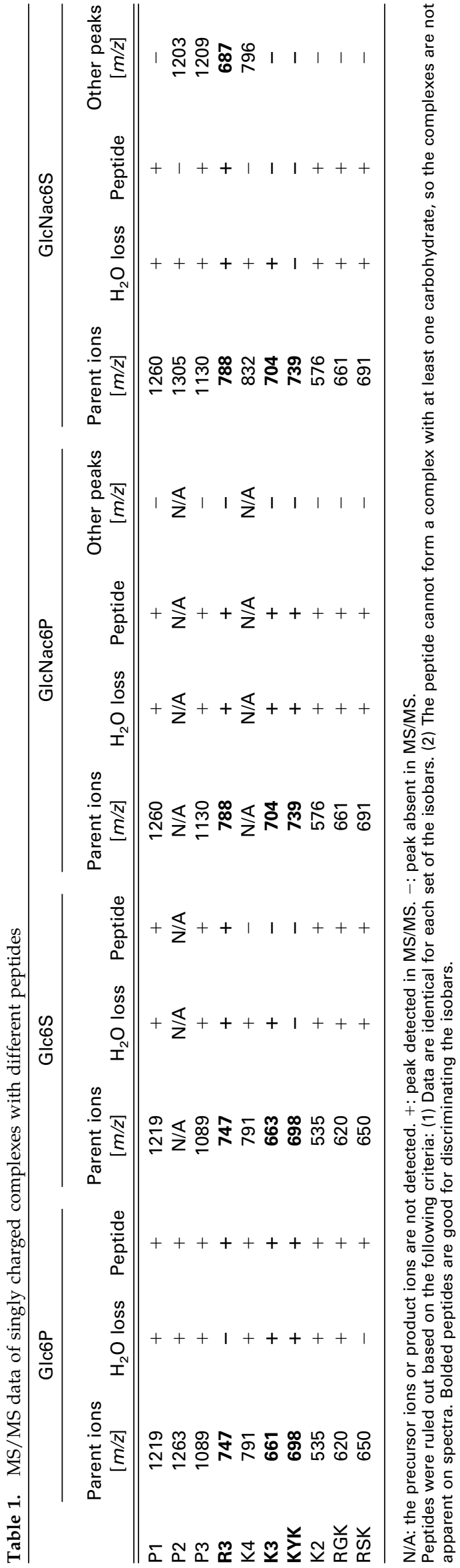

403, the doubly charged $\mathrm{K} 3$ at $\mathrm{m} / \mathrm{z} 202$, and two ions corresponding to the water loss from the ion-pair complex, labeled as $\left[\mathrm{M}-\mathrm{H}_{2} \mathrm{O}+2 \mathrm{H}\right]^{2+}$ and $\left[\mathrm{M}-2 \mathrm{H}_{2} \mathrm{O}+\right.$ $2 \mathrm{H}]^{2+}$, respectively. Water loss is generally expected in the MS/MS data of carbohydrates because of the presence of many hydroxyl groups in the carbohydrate's structure $[25,26] .{ }^{\circ}$ Two ${ }^{\circ}$ other ${ }^{\circ}$ singly ${ }^{\circ}{ }^{\circ}$ harged ${ }^{\circ}$ ions ${ }^{\circ}$ at ${ }^{\circ} \mathrm{m} / \mathrm{z}$ 261 and 243 corresponding to the product ion, [Glc6P + $\mathrm{H}^{+}$, and water loss from phosphorylated monosaccharide, respectively, were also observed.

In Figure $3 \mathrm{a}$, ${ }^{\circ}{ }^{\circ}{ }^{\circ}$ ion $^{\circ}{ }^{\circ}$ arresponding ${ }^{\circ}$ to ${ }^{\circ}$ the ${ }^{\circ}$ protonated monosaccharide $\left([\mathrm{Glc} 6 \mathrm{P}+\mathrm{H}]^{+}\right)$appears in the spectrum of the phosphorylated complex, [Glc6P $+\mathrm{K} 3+$ $2 \mathrm{H}]^{2+}$. This ion forms when the doubly charged complex dissociates to two singly charged ions, $[\mathrm{K} 3+\mathrm{H}]^{+}$ at $m / z 403$ and [Glc6P $+\mathrm{H}^{+}$at $m / z 261$. Doubly charged product ions dominate the spectrum of the sulfated complex, $[\mathrm{Glc} 6 \mathrm{~S}+\mathrm{K} 3+2 \mathrm{H}]^{2+}$. This indicates that the distribution of charges on the phosphorylated complex is different from that of the sulfated complex. The two protons on the phosphorylated complex are not exclusively located on the basic residue of the peptide. One of them can be transferred to the phosphate group of the carbohydrate. The difference in the charge distribution of the doubly charged sulfated and phosphorylated ion-pairs can be explained in terms of the proton affinities of the two functional groups. From the known $\mathrm{pKa}$ values of the sulfate $(\mathrm{pKa}=1.89)$ and the phosphate $^{\circ}$ group $^{\circ}\left(\mathrm{pKa}^{\circ}={ }^{\circ} 2.13\right)^{\circ}[27],{ }^{\circ}$ it $^{\circ} \mathrm{can}^{\circ}$ be $^{\circ}$ deduced $^{\circ}$ that the functional group with higher $\mathrm{pKa}$ has stronger proton affinity. Thus, the proton transfer from basic residue to the monophosphorylated residue is more facile, compared to the monosulfated carbohydrates.

Another difference in the dissociation between the sulfated and phosphorylated complexes is the product ion $\left[\mathrm{K} 3+\mathrm{SO}_{3}+2 \mathrm{H}\right]^{2+}$ at $\mathrm{m} / z 242$, which appears in

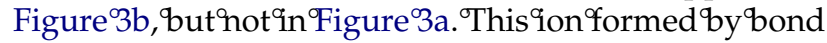
cleavage between the carbohydrate and the $\mathrm{SO}_{3}$ group. The $^{\circ}$ formation $^{\circ}$ of $^{\circ}$ this $^{\circ}$ ion $^{\circ}$ is ${ }^{\circ}$ likely $^{\circ}$ due $^{\circ}$ to ${ }^{\circ}$ stronger noncovalent interactions between the peptide and the sulfate group. Since the sulfate group has lower $\mathrm{pKa}$ than the phosphate group, it most likely complexes to the basic peptide residue more strongly. As a result, the covalent oxygen-sulfur bond cleaves, and the $\mathrm{SO}_{3}$ remains complexed to the ion-pairing reagent during CID. In contrast, the covalent phosphorus-oxygen bond does not cleave during CID. Because of the differences in chemical reactivity, the complexes have different fragmentation patterns when they undergo the same CID conditions.

Figure $3 \mathrm{c}^{\circ}$ and $^{\circ} \mathrm{d}^{\circ} \mathrm{show}^{\circ} \mathrm{MS} / \mathrm{MS}^{\circ}$ data ${ }^{\circ}$ for ${ }^{\circ}$ the ${ }^{\circ}$ two ${ }^{\circ}$ other isobaric species, GlcNAc6P and GlcNAc6S, complexed with K3. These two ion-pair complexes can also be

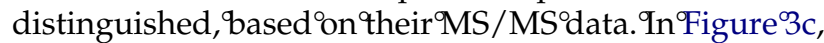
two singly charged complementary ions [GlcNAc6P + $\mathrm{H}]^{+}$and $[\mathrm{K} 3+\mathrm{H}]^{+}(\mathrm{m} / z 302$ and 403, respectively) originate from the precursor ion. These ions correspond to the ligand dissociation of the ion-pair complex. Only one other small product ion corresponding to the loss of 
water from the carbohydrate was observed, indicating that the interaction between phosphate and basic peptide was weaker than the covalent bonds in the phosphorylated monosaccharide. In addition to the two complementary ${ }^{\circ}$ ions ${ }^{\circ}$ observed ${ }^{\circ}{ }^{\circ}{ }^{\circ}$ igure $3 c^{\circ},{ }^{\circ}$ other ${ }^{\circ}$ product ions appear in the spectrum containing GlcNAc6S and $^{\circ} \mathrm{K} 3^{\circ}$ in $^{\circ}$ Figure $^{\circ} 3 \mathrm{~d}$. ${ }^{\circ}$ These ${ }^{\circ}$ ions ${ }^{\circ}$ include ${ }^{\circ}$ water ${ }^{\circ}$ loss ${ }^{\circ}$ ions $(\mathrm{m} / \mathrm{z} 344,335$, and 284) and the product ion at $\mathrm{m} / \mathrm{z} 222$, which corresponds to cleaving the oxygen-sulfur bond in the carbohydrate. Note that this covalent bond cleavage is only observed in the MS/MS data of the sulfated carbohydrates ${ }^{\circ}$ (Figure ${ }^{\circ} 3 b^{\circ}$ and $\left.{ }^{\circ} \mathrm{d}\right)$.

Another interesting observation in the MS/MS data in $^{\circ}$ Figure $^{\circ} 3 \mathrm{c}^{\circ}$ and $^{\circ} \mathrm{d}^{\circ}$ is ${ }^{\circ}$ that ${ }^{\circ}$ only ${ }^{\circ}$ the ${ }^{\circ}$ precursor ${ }^{\circ}$ and ${ }^{\circ}$ the product ions corresponding to the loss of $\mathrm{H}_{2} \mathrm{O}(\mathrm{m} / z 344$ and 335, respectively) are doubly charged. All of the other product ions are singly charged. This fragmentation behavior is different than the MS/MS data of the ion-pair complexes'shown ${ }^{\circ}{ }^{\circ}$ Figure $3 a^{\circ}$ and 9 . This 9 must be atributable to the type of carbohydrate complexed with the peptide. Hence, in addition to proton affinities, the type of carbohydrate is another important factor that can influence the ions formed in the CID spectra of phosphorylated and sulfated ion-pair complexes.

\section{Singly Charged Complexes with K3}

As discussed above, the MS data of the carbohydrate: peptide ion pairs show the formation of ion-pair complexes with different charge states: singly and doubly charge state complexes. MS/MS experiments were performed on the singly charged complexes; the sulfated and phosphorylated monosaccharides can also be distinguished ${ }^{\circ}$ using ${ }^{\circ}$ these ${ }^{\circ} \mathrm{CID}^{\circ}$ spectra $^{\circ}$ (Figure $\left.{ }^{\circ} 4\right)$. ${ }^{\circ}$ Three ${ }^{\circ}$ important ions were observed in the spectra: the molecular ions $\left(\mathrm{MH}^{+}\right)$, the ions corresponding to water loss $\left(\left[\mathrm{MH}-\mathrm{H}_{2} \mathrm{O}\right.\right.$ $+\mathrm{H}]^{+}$), and the singly charged peptides $\left(\left[\mathrm{K} 3+\mathrm{H}^{+}\right)\right.$. When identical collision conditions are used, the protonated ${ }^{\circ}$ peptide ${ }^{\circ} \mathrm{K} 3^{\circ}$ at ${ }^{\circ} \mathrm{m} / \mathrm{z} 403^{\circ}$ in ${ }^{\circ}$ Figure $^{\circ} 4^{\circ}{ }^{\circ} s^{\circ}$ observed ${ }^{\circ}$ upon CID in the MS/MS data of the phosphorylated complex, but not in the data of the sulfated complex. The presence of these singly charged peptide product ions [K3 $+\mathrm{H}]^{+}$ provide additional evidence that phosphorylated ion-pair complexes are weaker than the sulfated ion-pair complexes, because the sulfated complexes undergo the covalent cleavage only (loss of $\mathrm{H}_{2} \mathrm{O}$ ), while the phosphorylated complexes undergo cleavage of the noncovalent interaction. This method of differentiating the isobars is dependent on the collision energy used. At higher collision energies, the sulfated complexes also undergo ligand dissociation.

\section{Application to Other Phosphorylated and Sulfated Monosaccharides}

The ion-pairs with different charge states have different fragmentation characteristics based on the observations discussed above. Doubly charged sulfated

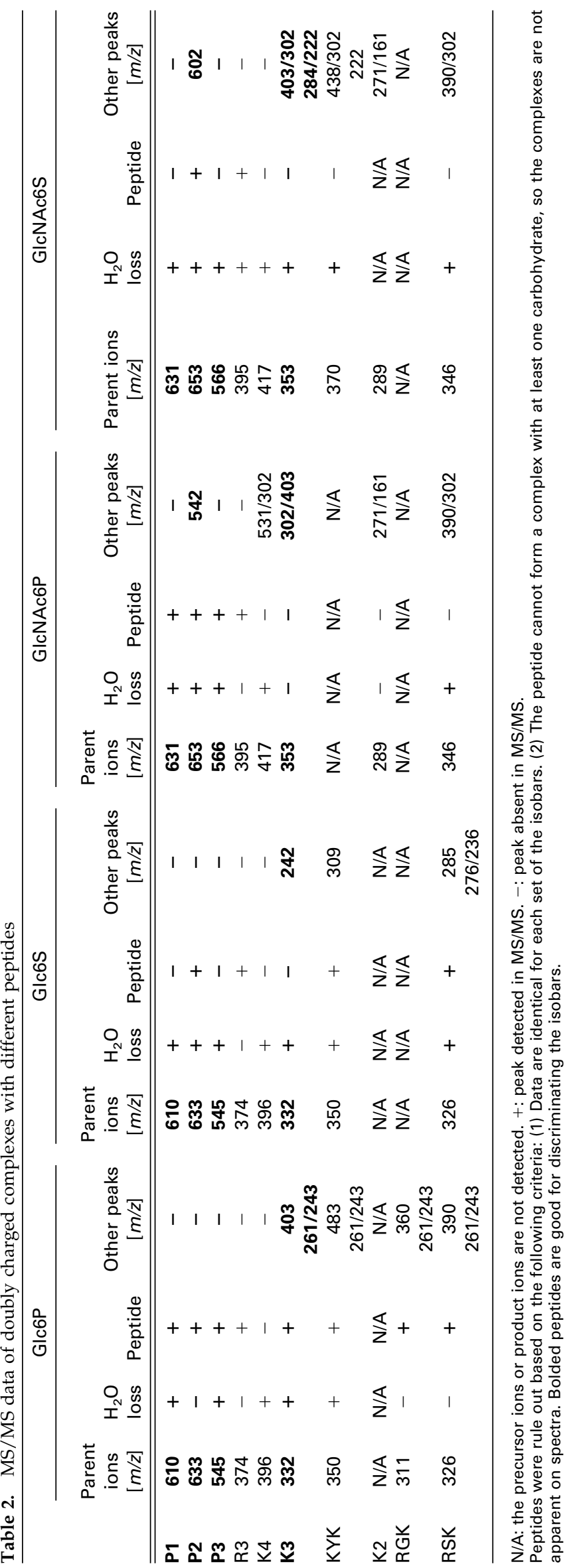


(a) $[\mathrm{Glc} 6 \mathrm{P}+\mathrm{K} 3+2 \mathrm{H}]^{2+}$

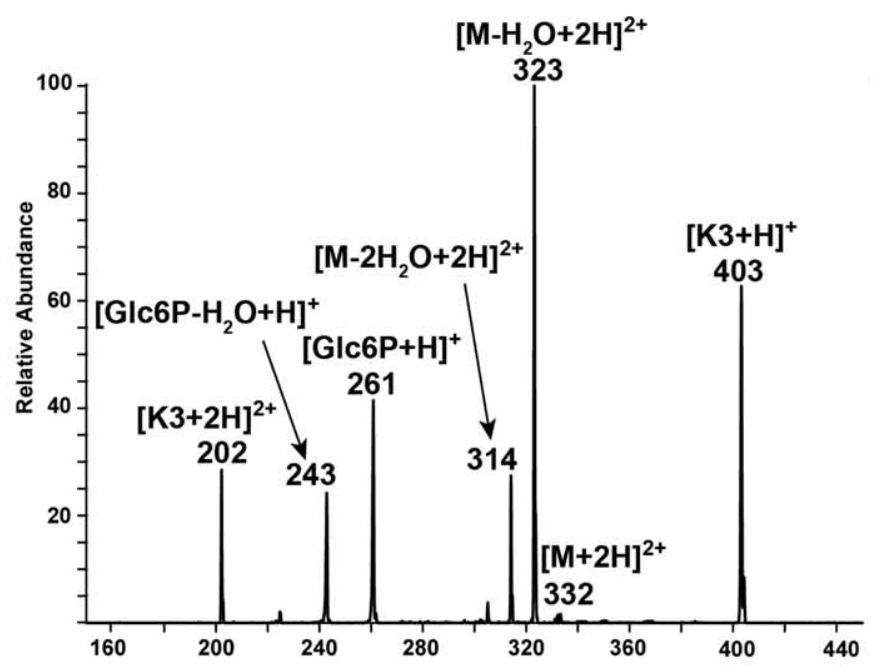

(c) $[\mathrm{GlcNAc} 6 \mathrm{P}+\mathrm{K} 3+2 \mathrm{H}]^{2+}$

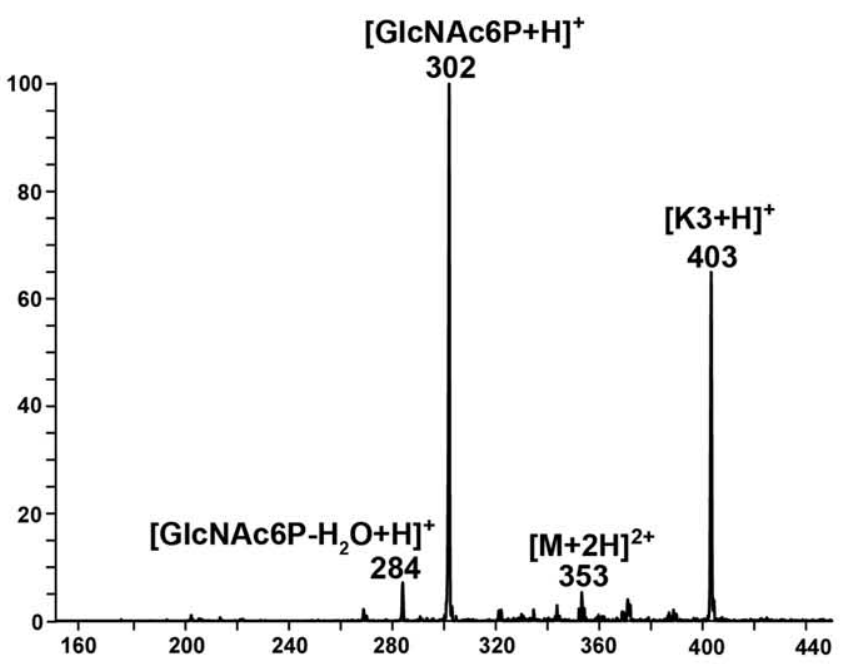

(b) $[\mathrm{Glc} 6 \mathrm{~S}+\mathrm{K} 3+2 \mathrm{H}]^{2+}$

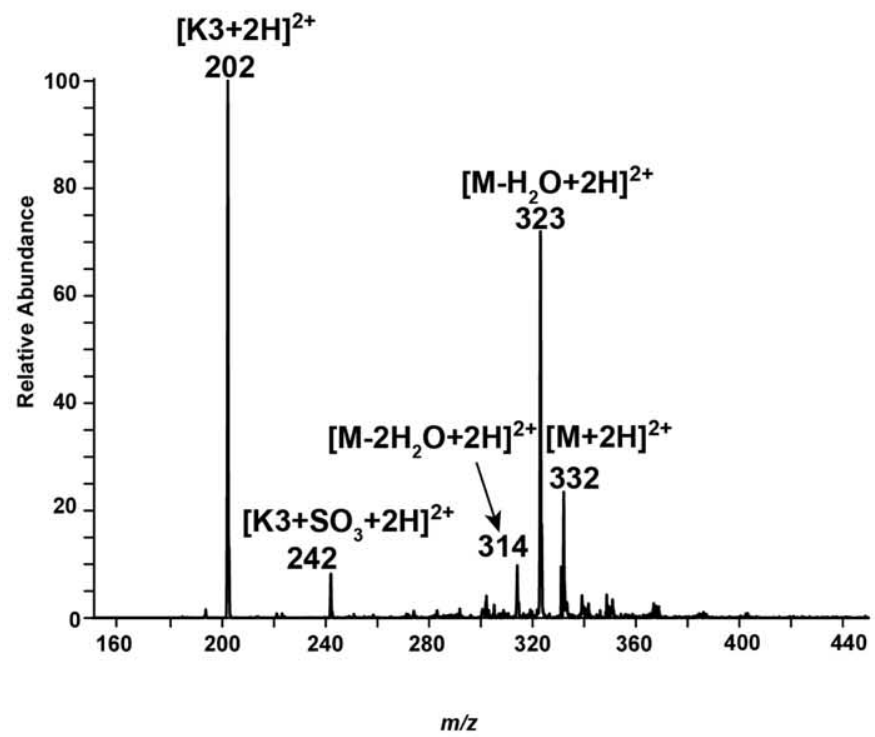

(d) $[\mathrm{GICNAc6S}+\mathrm{K} 3+2 \mathrm{H}]^{2+}$

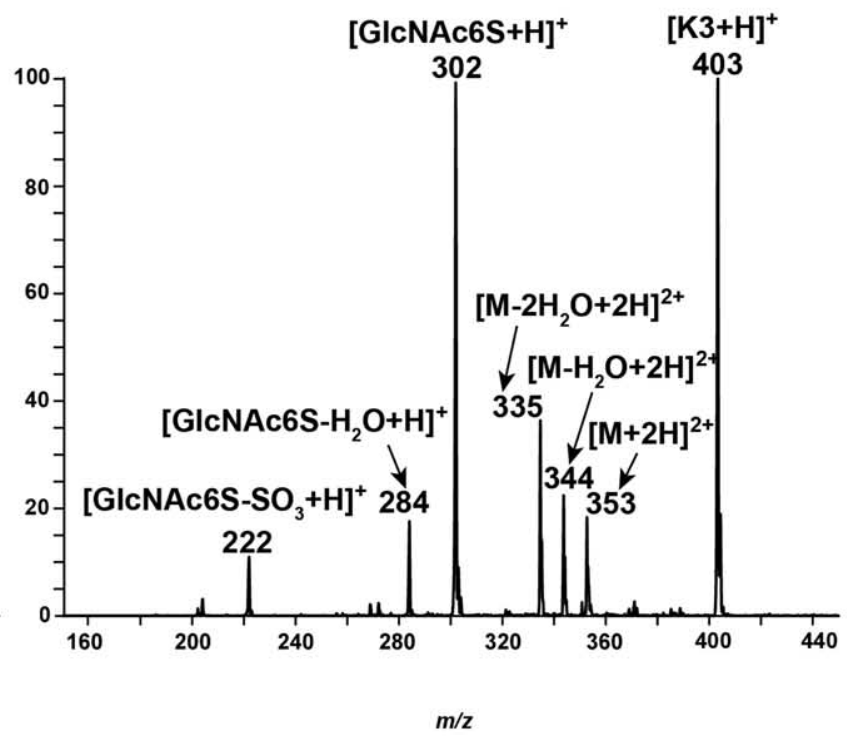

Figure 3. (+)ESI-MS/MS data for the doubly charged ion-pairs with Lys-Lys-Lys (K3): (a) phosphorylated complex $[\mathrm{Glc} 6 \mathrm{P}+\mathrm{K} 3+2 \mathrm{H}]^{2+},(\mathbf{b})$ sulfated complex [Glc6S $\left.+\mathrm{K} 3+2 \mathrm{H}\right]^{2+}$, (c) phosphorylated complex [GlcNAc6P $+\mathrm{K} 3+2 \mathrm{H}]^{2+}$, and (d) sulfated complex [GlcNAc6S + K3 + $2 \mathrm{H}]^{2+}$. (b) and (d) both show characteristic ions resulting from oxygen-sulfur bond cleavage.

compounds produce ions that correspond to cleavage of the oxygen-sulfur bond, resulting in losses of $\mathrm{SO}_{3}$ in the MS/MS data, while phosphorylated compounds are more likely to undergo ligand dissociation to produce the protonated carbohydrates, instead of covalent bond cleavages. When singly charged ion-pair complexes undergo CID, the dissociation of the noncovalent complex occurs more readily for the phosphorylated compounds. This results in formation of the product ions
$[\mathrm{K} 3+\mathrm{H}]^{+}$in the CID data of the phosphorylated complexes. To test whether the chemical reactivity trends observed for the four isobaric monosaccharides are conserved when slight changes in the monosaccharides occur, the ion pairing MS/MS experiments were applied to other commercially available phosphorylated and sulfated monosaccharides.

The structures of the monosaccharides shown in Scheme ${ }^{\circ}{ }^{\circ}$ include $^{\circ} \mathrm{N}$-acetyl-glucosamine-1-phosphate 
(a) $[\mathrm{Glc} 6 \mathrm{P}+\mathrm{K} 3+\mathrm{H}]^{+}$

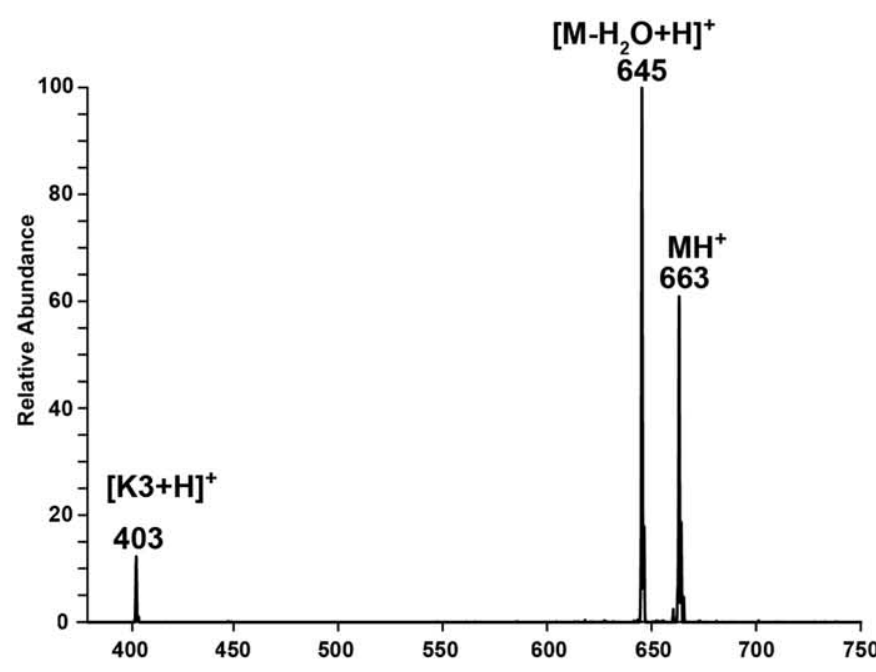

\section{(c) $[\mathrm{GlcNAc6P}+\mathrm{K} 3+\mathrm{H}]^{+}$}

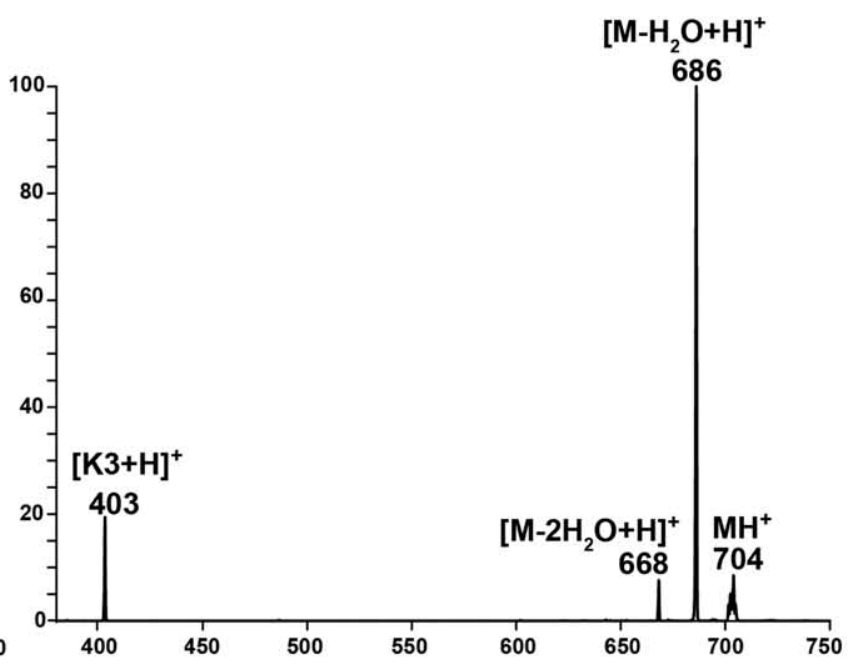

(b) $[\mathrm{Glc} 6 \mathrm{~S}+\mathrm{K} 3+\mathrm{H}]^{+}$

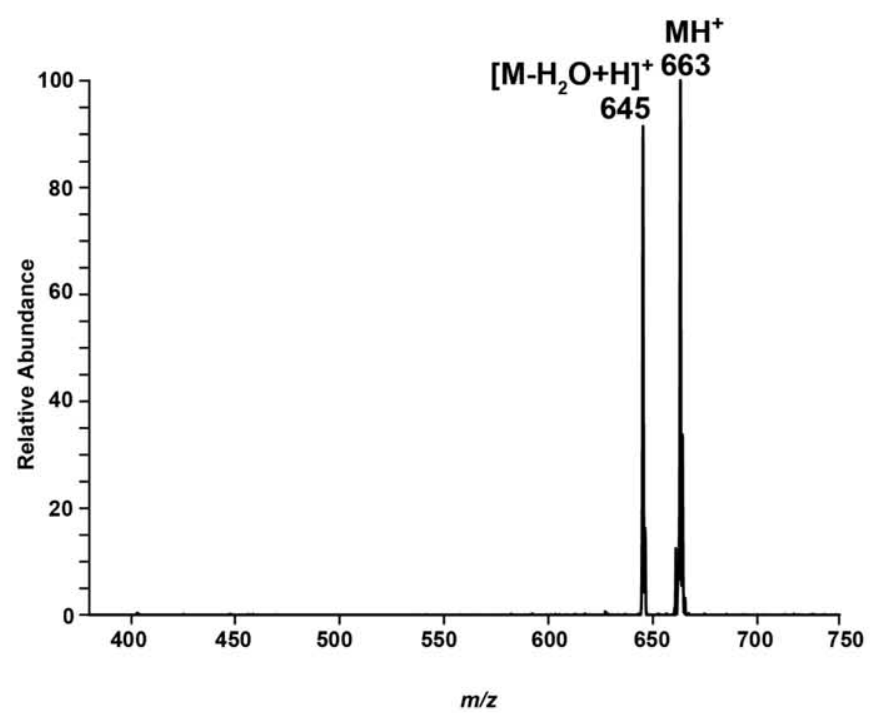

(d) $[\mathrm{GICNA} 6 \mathrm{~S}+\mathrm{K} 3+\mathrm{H}]^{+}$

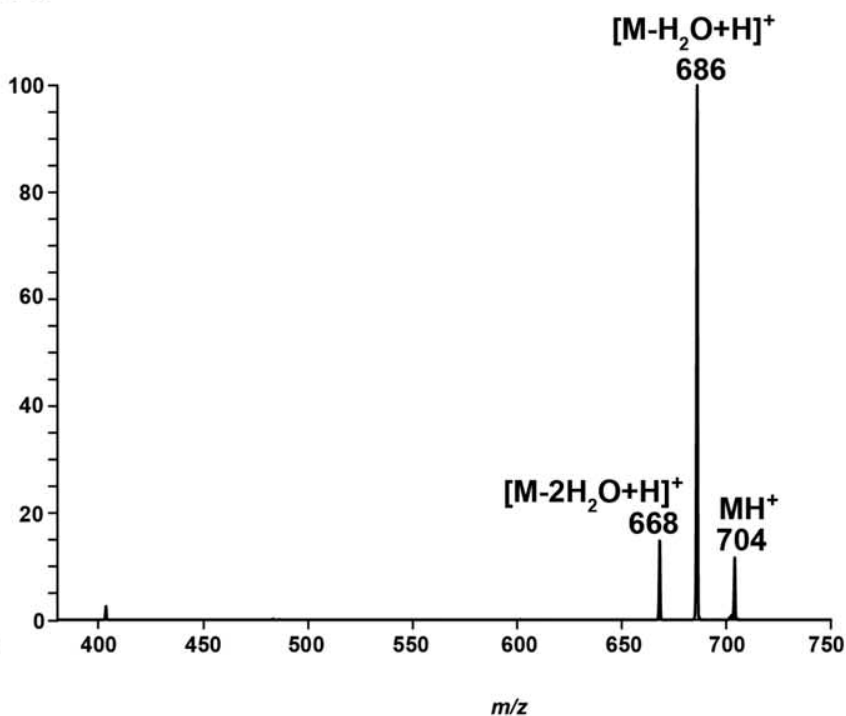

Figure 4. (+)ESI-MS/MS data for singly charged complexes with Lys-Lys-Lys (K3) to identify the difference in chemical reactivity between phosphate and sulfate of the following carbohydrate:peptide complexes: (a) phosphorylated ion-pair complex [Glc6P $+\mathrm{K} 3+\mathrm{H}]^{+},(\mathbf{b})$ sulfated ion-pair complex $[\mathrm{Glc6S}+\mathrm{K} 3+\mathrm{H}]^{+}$, (c) phosphorylated ion-pair complex [GlcNAc6P $\left.+\mathrm{K} 3+\mathrm{H}\right]^{+}$, and (d) sulfated ion-pair complex [GlcNAc6S $+\mathrm{K} 3+\mathrm{H}^{+}$.

(GlcNAc1P), N-acetyl-galactosamine-4-sulfate (GalNAc4S), glucose-3-sulfate (Glc3S), and isomers $\alpha$-glucose-1-phosphate ( $\alpha$ Glc1P) and $\beta$-glucose-1phosphate ( $\beta$ Glc1P).

MS/MS data of the doubly charged ion-pair complexes of the sulfated and phosphorylated carbohydrates ${ }^{\circ}$ omplexed with ${ }^{\circ} 3^{\circ}$ are ${ }^{\circ}$ hown in Figure 5 . Figure $5 \mathrm{a}^{\circ}$ and $^{\circ} \mathrm{b}^{\circ}$ are $^{\circ}$ two $^{\circ}$ phosphorylated ${ }^{\circ}$ isomers ${ }^{\circ} \alpha$-Glc1 $1 \mathrm{P}^{\circ}$ and $\beta$-Glc1P complexed with K3, while the two N-acetylhexosamine:peptide ion pairs [GlcNAc1P $+\mathrm{K} 3+2 \mathrm{H}]^{2+}$ and ${ }^{\circ}\left[\mathrm{GalNAc} 4 \mathrm{~S}^{\circ}+{ }^{\circ} \mathrm{K} 3^{\circ}+{ }^{\circ} 2 \mathrm{H}\right]^{2+}{ }^{\circ}$ are $^{\circ}$ shown ${ }^{\circ}$ in ${ }^{\circ}$ Figure $^{\circ} 5 \mathrm{~d}$ and e.

The two $\mathrm{N}$-acetylhexosamines are readily distinguished in this experiment. Two complementary ions, protonated hexosamine [GlcNAc1P $+\mathrm{H}]^{+}(\mathrm{m} / \mathrm{z} 302)$ and peptide ion $[\mathrm{K} 3+\mathrm{H}]^{+}(m / z 403)$ are shown in Figure ${ }^{\circ} \mathrm{d},{ }^{\circ}$ which $^{\circ}$ is $^{\circ}$ consistent $^{\circ}$ with $^{\circ}$ the ${ }^{\circ}$ trends ${ }^{\circ}$ of ${ }^{\circ}$ dissociation of phosphorylated ion pairs upon CID. The ion $(\mathrm{m} / \mathrm{z} 204)$ is most likely a secondary product resulting from $^{\circ}$ the ${ }^{\circ}$ fragmentation ${ }^{\circ}$ of $^{\circ}$ the ${ }^{\circ}$ ion $^{\circ}$ at $^{\circ} \mathrm{m} / \mathrm{z} 302$. In $^{\circ}$ Figure 


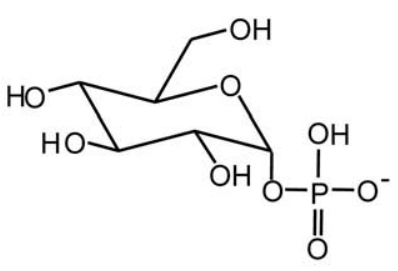

a-Glucose-1-phosphate aGlc1P

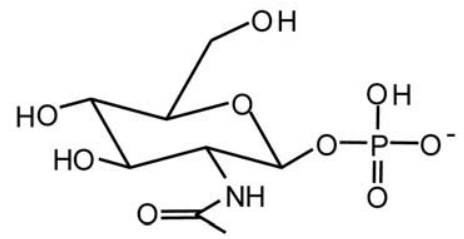

N-acetyl-glucosamine-1-phosphate GIcNAc1P
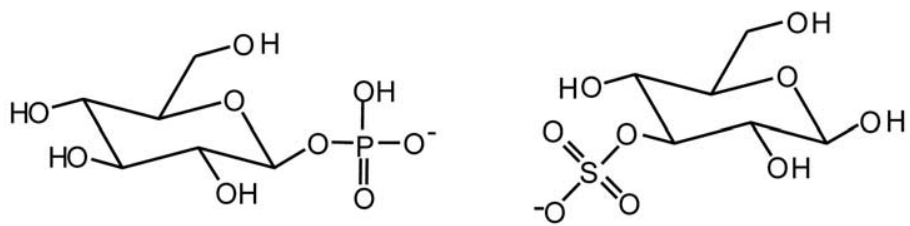

$\beta$-Glucose-1-phosphate $\beta$ GIc1P

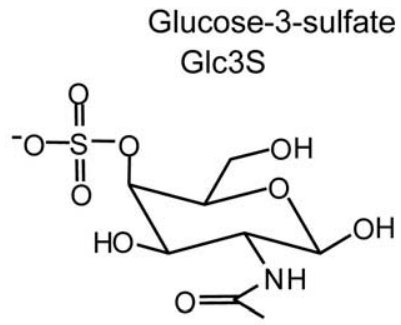

$\mathrm{N}$-acetyl-galactosamine-4-sulfate GalNAc4S

Scheme 2

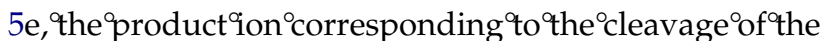
oxygen-sulfur bond is labeled at $\mathrm{m} / \mathrm{z} 222$ which corresponds to [GalNAc4S $\left.-\mathrm{SO}_{3}+\mathrm{H}\right]^{+}$. This ion clearly indicates that the monosaccharide is sulfated and not phosphorylated.

The data for the hexose monosaccharides is also consistent with the trends established for the CID spectra $^{\circ}$ of ${ }^{\circ}$ the $^{\circ}$ isobaric $^{\circ}$ monosaccharides ${ }^{\circ}$ in $^{\circ}$ Figure $^{\circ} 3$. Two product ions $(\mathrm{m} / \mathrm{z} 261$ and 403) originating from the ligand dissociation are apparent in the spectra of phosphorylated complexes $[\alpha \mathrm{Glc} 1 \mathrm{P}+\mathrm{K} 3+2 \mathrm{H}]^{2+}$, Figure $^{\circ} 5 \mathrm{a}^{\circ}$ and ${ }^{\circ}\left[\beta \mathrm{Glc} 1 \mathrm{P}^{\circ}+{ }^{\circ} \mathrm{K} 3^{\circ}+{ }^{\circ} 2 \mathrm{H}\right]^{2+},{ }^{\circ}$ Figure ${ }^{\circ} 5 \mathrm{~b} .{ }^{\circ}$ The product ion at $m / z 242$ corresponding to the oxygensulfur ${ }^{\circ}$ bond $^{\circ}$ cleavage $^{\circ}$ appears ${ }^{\circ}$ in $^{\circ}$ Figure $^{\circ} 5 \mathrm{c} .{ }^{\circ}$ However, these three characteristic product ions that are useful to discriminate the hexoses are not present in abundance. To further verify the different fragmentation characteristics of both phosphorylated and sulfated hexoses: peptide ion-pair complexes upon collisional activation, peptide KYK was introduced in the analysis.

Figure $^{\circ} 6^{\circ}$ shows $^{\circ}$ the ${ }^{\circ} \mathrm{MS} \mathrm{MS}^{\circ}$ data $^{\circ}$ of $^{\circ}$ the $^{\circ}$ doubly charged hexoses:peptide ion-pairs. The observed difference between the MS/MS data of the ion-pair complexes ${ }^{\circ}$ in $^{\circ}$ Figure $^{\circ} 6 \mathrm{a}^{\circ}$ and $^{\circ} \mathrm{b}^{\circ}{ }^{\circ}$ which ${ }^{\circ}$ are $^{\circ}$ model $^{\circ}$ isobaric molecules, are consistent with the trends discussed above. Two complementary product ions at $\mathrm{m} / \mathrm{z} 260.9$ and 438.3 are originating from the ligand dissociation in Figure $6 \mathrm{a}$, while ${ }^{\circ}$ an ${ }^{\circ}{ }^{\circ}$ corresponding ${ }^{\circ} 0^{\circ}$ oxygen-sulfur bond ${ }^{\circ}$ Cleavage ${ }^{\circ}$ appears ${ }^{\circ}$ in $^{\circ}$ Figure $^{\circ} 6 \mathrm{~b},{ }^{\circ}$ along ${ }^{\circ}$ with ${ }^{\circ}$ many other product ions resulting from the covalent bond cleavages. This demonstrates that peptide KYK is useful to distinguish doubly charged hexoses:peptide ion pairs. ${ }^{\circ}$ From $^{\circ}$ the $^{\circ}$ other ${ }^{\circ}$ spectra ${ }^{\circ}$ in $^{\circ}$ Figure $^{\circ} 6,{ }^{\circ}$ the ${ }^{\circ}$ relative abundance of the ions corresponding to the noncovalent cleavage in phosphorylated complexes (ions at $\mathrm{m} / \mathrm{z}$ $260.9^{\circ}$ and $^{\circ} 438.1^{\circ}$ in $^{\circ}$ Figure $^{\circ} 6 \mathrm{c}^{\circ}$ and $\left.^{\circ} \mathrm{d}\right)^{\circ}$ and ${ }^{\circ}$ oxygen-sulfur cleavage in sulfated complexes (ion at $\mathrm{m} / \mathrm{z} 309.4$ in Figure $\left.^{\circ} 6 \mathrm{e}\right)^{\circ}$ are $^{\circ}$ enhanced $^{\circ}$ when $^{\circ} \mathrm{KYK}^{\circ}$ is ${ }^{\circ}$ used $^{\circ}$ as $^{\circ}$ the ion-pairing reagent, instead of $\mathrm{K} 3$. This peptide provides the complementary information to confirm the fragmentation characteristics of hexoses:peptide ion pairs. To summarize, the peptide $\mathrm{K} 3$ was useful at distinguishing the monosaccharides, but the important discriminating ions were in low abundance. The identity of each of the monosaccharides could be further supported using another peptide that discriminated the hexoses, KYK.

Aside from the doubly charged ion pairs, the CID data of the singly charged ion pairs are summarized in Table ${ }^{\circ}$. Upon ${ }^{\circ}$ collisional ${ }^{\circ}$ activation, ${ }^{\circ}$ the ${ }^{\circ}$ singly ${ }^{\circ}$ charged phosphorylated ion-pair complexes dissociate to produce the abundant peptide $[\mathrm{K} 3+\mathrm{H}]^{+}$. This ion is useful to distinguish phosphorylated and sulfated complexes. These results are consistent with the MS/MS data for the ${ }^{\circ}$ original ${ }^{\circ}$ four ${ }^{\circ}$ isobaric ${ }^{\circ}$ monosaccharides ${ }^{\circ}$ in $^{\circ}$ Figure $^{\circ} 4$. Using the singly charged complexes to differentiate the hexose monosaccharides represents a third successful approach to identifying the chemical composition of these monosaccharides. Clearly, the ion pairing strategy is robust in that it is useful under many conditions, for various types of monosaccharides, various charge states, and various ion-pairing reagents.

These data also demonstrate that the rules developed to describe the dissociation of the isobaric monosaccharides could be applied to any other sulfated or phosphorylated monosaccharide. Since these rules appear to be functional group specific, and not compound specific, it is quite plausible that these principles could be extended to larger oligosaccharides or glycopeptides. Overall, the comparison of the MS/MS data of both abundant ionpairs demonstrates that ion-pairing reagents, K3 and KYK, can be used to effectively distinguish phosphorylated and sulfated compounds in terms of their fragmentation characteristics in the CID spectra.

While differentiating positional isomers is not the subject of this investigation, ion-pairing may also be 
(a) $[\alpha \mathrm{GIc1P}+\mathrm{K} 3+2 \mathrm{H}]^{2+}$

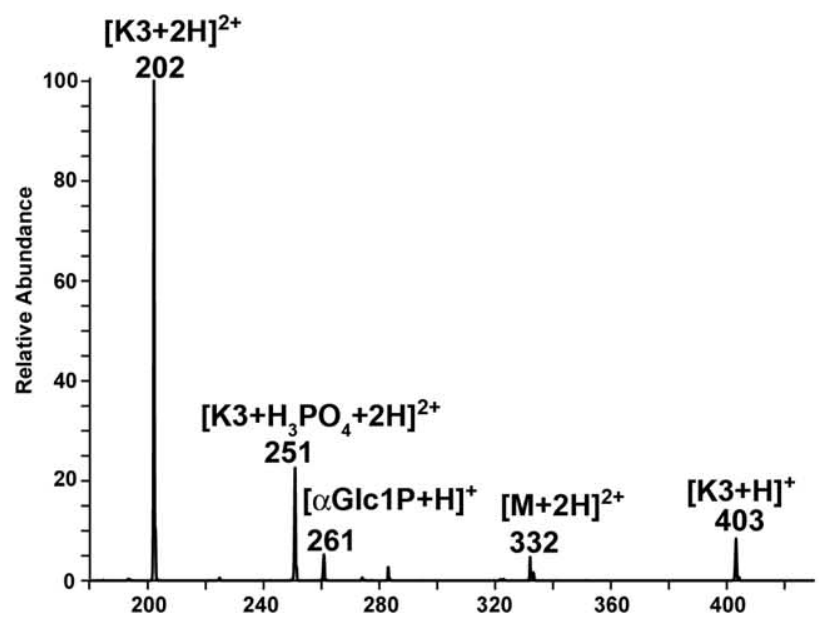

(b) $[\beta G I c 1 P+K 3+2 H]^{2+}$

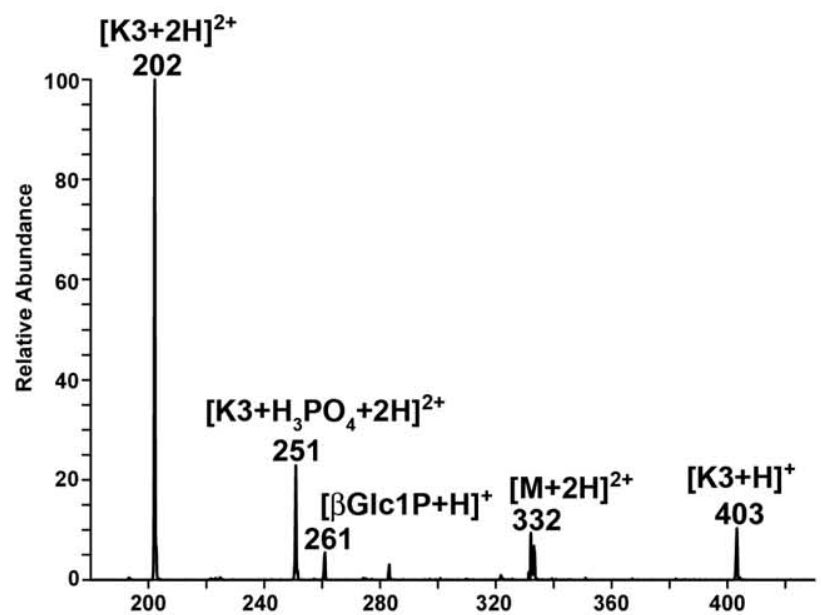

(c) $[\mathrm{Glc} 3 \mathrm{~S}+\mathrm{K} 3+2 \mathrm{H}]^{2+}$

$[\mathrm{K} 3+2 \mathrm{H}]^{2+}$

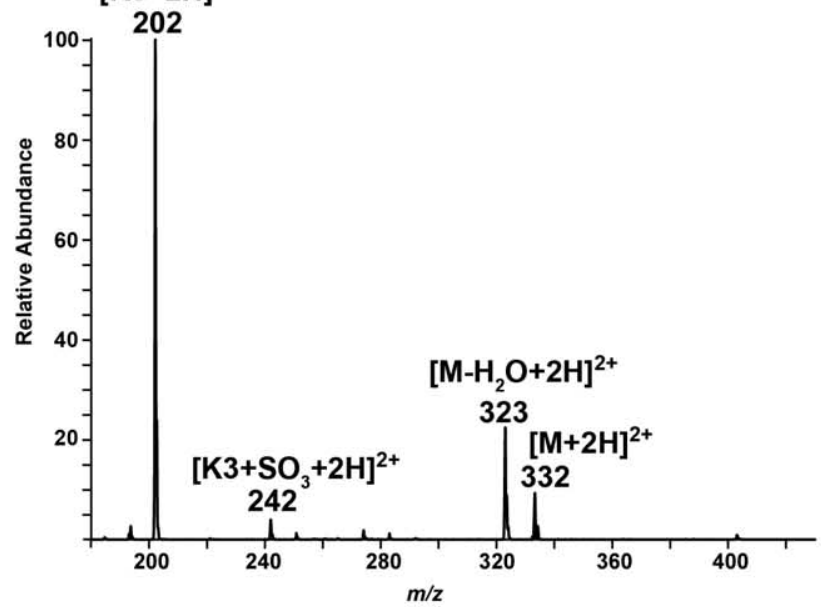

(d) $[\mathrm{GICNAC1P}+\mathrm{K} 3+2 \mathrm{H}]^{2+}$

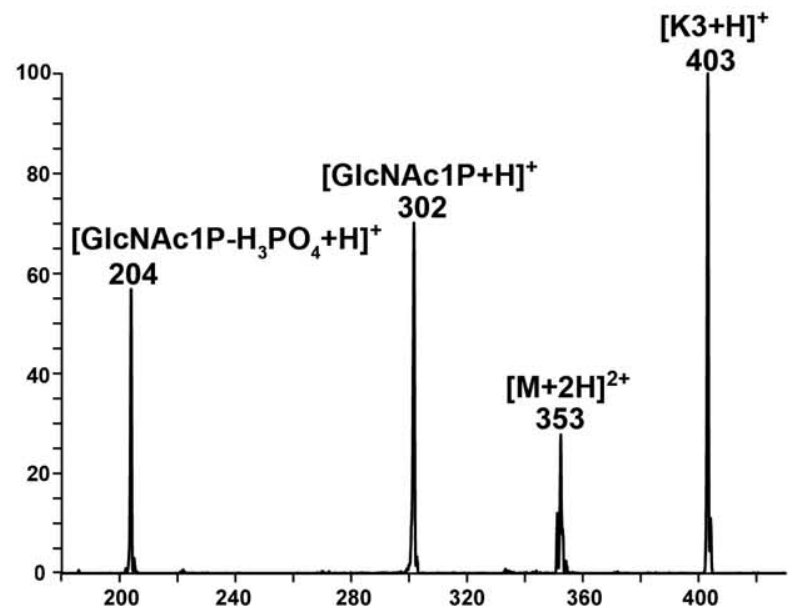

(e) $[\text { GalNAc4S }+\mathrm{K} 3+2 \mathrm{H}]^{2+}$

$\left[\mathrm{GIcNAC4S}-\mathrm{SO}_{3}+\mathrm{H}\right]^{+}$

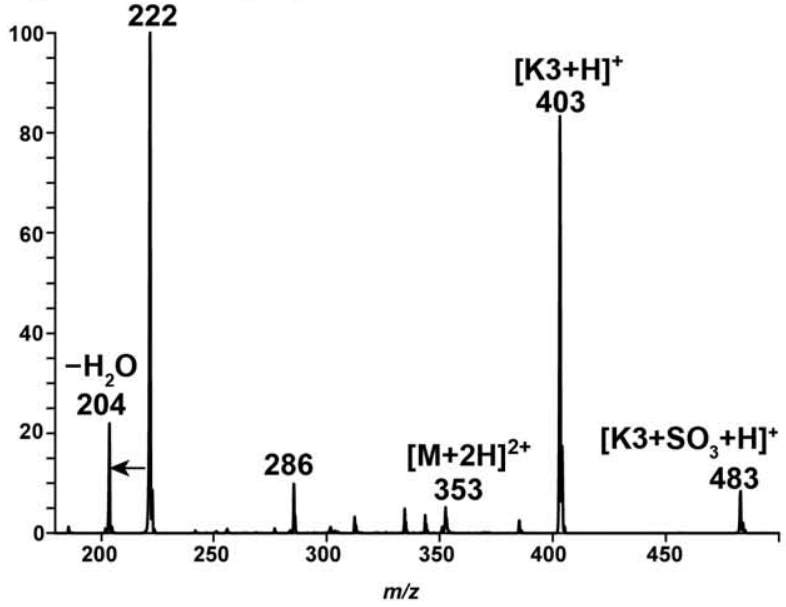

Figure 5. (+)ESI-MS/MS data for the doubly charged ion-pair complexes with the tripeptide Lys-Lys-Lys (K3) verifying which species were sulfated or phosphorylated of the following carbohydrate:peptide complexes: (a) phosphorylated complex $[\alpha \mathrm{Glc} 1 \mathrm{P}+\mathrm{K} 3+2 \mathrm{H}]^{2+},(\mathbf{b})$ phosphorylated complex $[\beta \mathrm{Glc} 1 \mathrm{P}+\mathrm{K} 3+2 \mathrm{H}]^{2+}$, (c) sulfated complex $[\mathrm{Glc} 3 \mathrm{~S}+\mathrm{K} 3+2 \mathrm{H}]^{2+}$, (d) phosphorylated complex [GlcNAc1P $+\mathrm{K} 3+2 \mathrm{H}]^{2+}$, and (e) sulfated complex [GalNAc4S $\left.+\mathrm{K} 3+2 \mathrm{H}\right]^{2+}$. (c) and (e) both show characteristic ions resulting from oxygen-sulfur bond cleavage. 
(a) $[\mathrm{Glc} 6 \mathrm{P}+\mathrm{KYK}+2 \mathrm{H}]^{2+}$

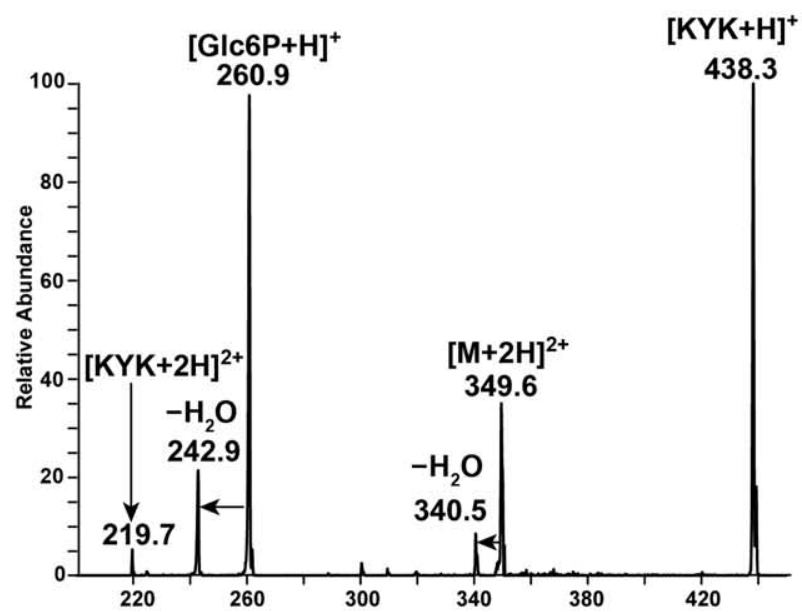

(b) $[\mathrm{GIc} 6 \mathrm{~S}+\mathrm{KYK}+2 \mathrm{H}]^{2+}$

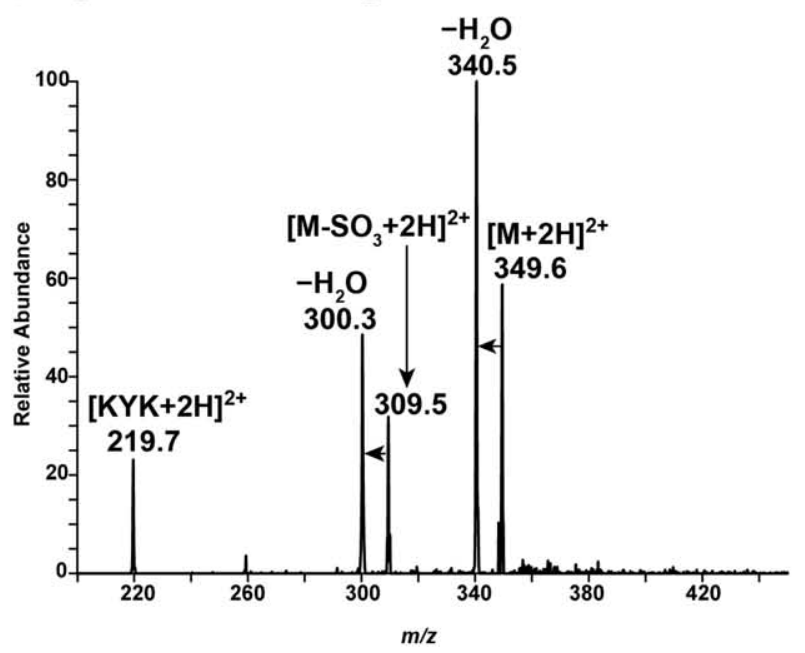

(c) $[\alpha \mathrm{Glc1P}+\mathrm{KYK}+2 \mathrm{H}]^{2+}$

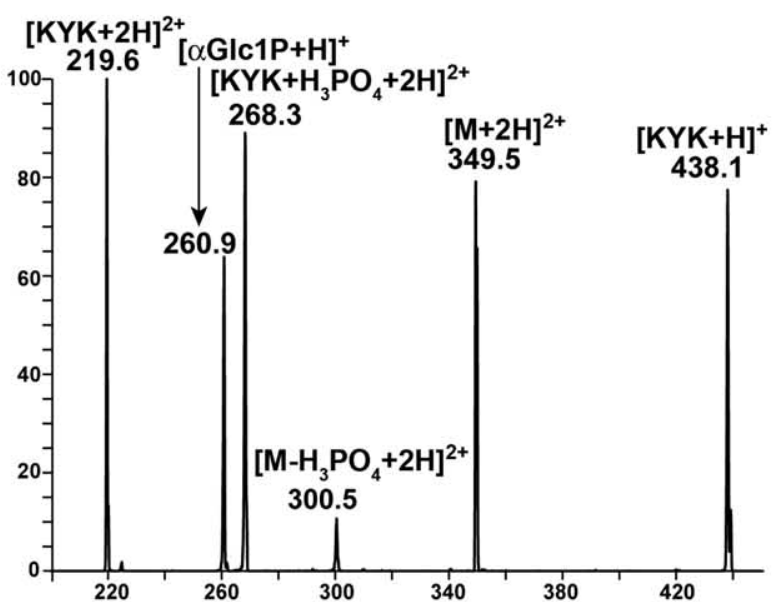

(d) $[\beta G I c 1 P+K Y K+2 H]^{2+}$

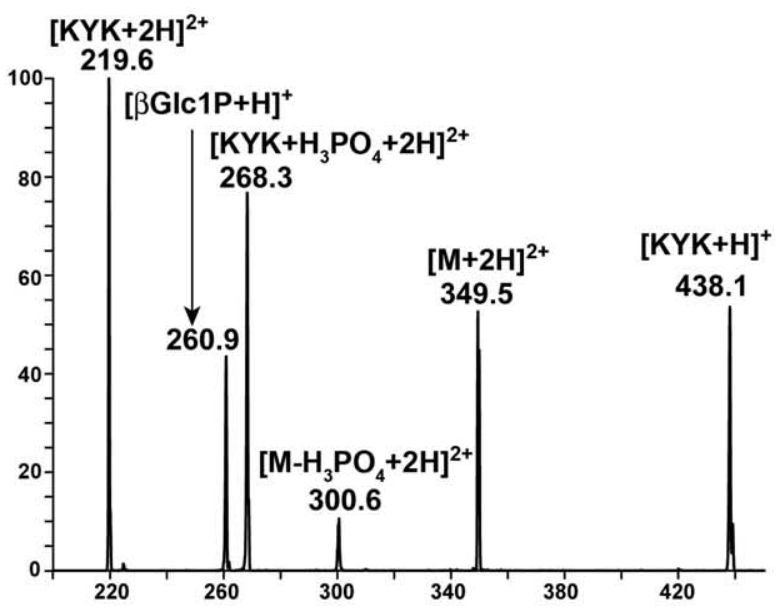

(e) $[\mathrm{GIc} 3 \mathrm{~S}+\mathrm{KYK}+2 \mathrm{H}]^{2+}$

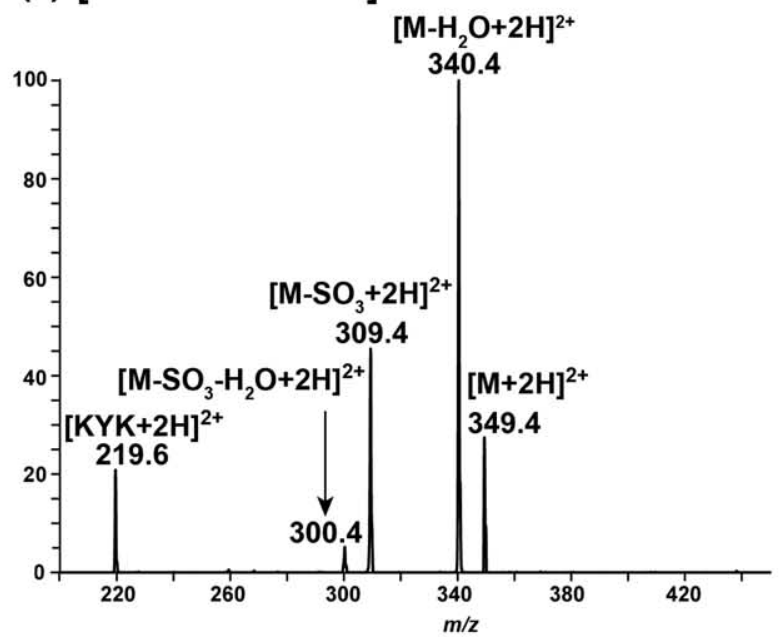

Figure 6. (+)ESI-MS/MS data for the doubly charged ion-pair complexes with Lys-Tyr-Lys (KYK) (a) phosphorylated complex [Glc6P $+\mathrm{KYK}+2 \mathrm{H}]^{2+}$, (b) sulfated complex [Glc6S $\left.+\mathrm{KYK}+2 \mathrm{H}\right]^{2+}$, (c) phosphorylated complex $[\alpha \mathrm{Glc} 1 \mathrm{P}+\mathrm{KYK}+2 \mathrm{H}]^{2+}$, (d) phosphorylated complex $[\beta \mathrm{Glc} 1 \mathrm{P}+\mathrm{KYK}+$ $2 \mathrm{H}]^{2+}$, and (e) sulfated complex [Glc3S $\left.+\mathrm{KYK}+2 \mathrm{H}\right]^{2+}$. 
Table 3. MS/MS data of singly charged complexes with K3

\begin{tabular}{|c|c|c|c|c|c|}
\hline \multicolumn{3}{|c|}{$[\mathrm{HexNAcs}+\mathrm{K} 3]^{+}$} & \multicolumn{3}{|c|}{$[\text { Hexoses }+\mathrm{K} 3]^{+}$} \\
\hline HexNAcs & $\begin{array}{c}\text { Parent ions } \\
m / z\end{array}$ & $\begin{array}{l}{[\mathrm{K} 3+\mathrm{H}]^{+} \mathrm{m} / \mathrm{z} 403} \\
\text { (abundance \%) }\end{array}$ & Hexoses & $\begin{array}{c}\text { Parent ions } \\
m / z\end{array}$ & $\begin{array}{c}{[\mathrm{K} 3+\mathrm{H}]^{+} \mathrm{m} / \mathrm{z} 403} \\
\text { (abundance \%) }\end{array}$ \\
\hline GlcNAc6P & 704 & 18 & Glc6P & 663 & 15 \\
\hline GlcNAc1P & 704 & 100 & $\alpha \mathrm{Glc} 1 \mathrm{P}$ & 663 & 10 \\
\hline GlcNAc6S & 704 & $\mathrm{~N} / \mathrm{A}$ & $\beta$ GIc1P & 663 & 10 \\
\hline GlcNAc4S & 704 & $\mathrm{~N} / \mathrm{A}$ & Glc6S & 663 & $\mathrm{~N} / \mathrm{A}$ \\
\hline & & & Glc3S & 663 & $\mathrm{~N} / \mathrm{A}$ \\
\hline
\end{tabular}

N/A: The product ions are not detected.

useful for identifying the location of the phosphate on the monosaccharides. A unique product ion is present in ${ }^{\circ}$ Figure ${ }^{\circ} 5^{\circ}$ and $^{\circ} 6^{\circ}$ for ${ }^{\circ}$ the ${ }^{\circ}$ monosaccharides ${ }^{\circ}$ phosphorylated at the anomeric carbon. This product ion corresponds to cleavage of $\mathrm{H}_{3} \mathrm{PO}_{4}$ from the monosaccharides. When the phosphate is at the $\mathrm{C} 6$ position, a loss of $\mathrm{H}_{2} \mathrm{O}$ is observed instead. A possible explanation for this behavior is that the water loss from Glc6P and GlcNAc6P is coming from the hydroxyl group of $\mathrm{C} 1$. Once the hydroxyl group is replaced by the phosphate group, a carbohydrate/phosphate cleavage occurs instead. This hypothesis is also supported by the observation that the complexes produced from Glc1P or GlcNAc1P do not have water loss product ions in their CID spectra.

\section{Potential Application to Biological Samples}

Phosphorylation and sulfation of glycoproteins and glycopeptides are involved in a variety of significant biological functions. Differentiation between these species is crucial in the characterization of structure/ function relationship of modified glycoprotein or glycopeptides. As discussed above, the peptides K3 and KYK are effective ion-pairing reagents to distinguish phosphorylated and sulfated carbohydrates. Since KYK cannot readily form complexes with some monosaccharides, $\mathrm{K} 3$ is a potential ion-pairing reagent that can be used to distinguish sulfate and phosphate biological systems. In a previous study, K3 has been utilized to complex with mono- and disulfated glycopeptides to enhance the signal in the positive ion mode of ESI-MS and provide structural information ${ }^{\circ}$ about $^{\circ}$ the $^{\circ}$ sulfated ${ }^{\circ}$ glycopeptides $^{\circ}[20]$. Also, the results presented herein indicate that the phosphorylated carbohydrates can also complex with the ion-pairing reagents in good abundance in ESIMS. This implies that K3 can potentially be applied to distinguish between phosphorylated and sulfated glycopeptides. A full investigation of the utility of ion-pairing for differentiation analysis of phosphorylated and sulfated glycopeptides is ongoing and will be presented separately.

\section{Conclusions}

In this manuscript, all the commercially available sulfated and phosphorylated monosaccharides are differentiated using ion-pairing and MS/MS. Furthermore, this method is robust because it is effective regardless of the charge state of the ion-pair. The fragmentation characteristics in the CID spectra for both abundant ion-pairs were summarized. For doubly charged complexes, sulfated compounds are likely to undergo sulfur-oxygen bond cleavage, while phosphorylated compounds tend to dissociate by disrupting noncovalent interactions. The type of monosaccharide also affects the MS data of the ion pairs, but it does not affect the characteristic product ions that are useful at discriminating between sulfate and phosphate.

MS/MS data of singly charged ion pairs also support the hypothesis that phosphorylated ion-pair complexes are weaker than the sulfated ion-pair complexes, because the sulfated complexes undergo covalent cleavage only, while the phosphorylated complexes undergo cleavage of the noncovalent interaction.

This is the first example of using ion-pairing on phosphorylated compounds and the first use of ionpairing reagents to discriminate the presence of sulfates and phosphates. Since we have recently demonstrated that the ion-pairing method enhances the mass spectral signal of sulfated glycopeptides that are minor components $^{\circ}(<5 \%)^{\circ}$ of $^{\circ}$ glycopeptide $^{\circ}$ mixtures $^{\circ}\left[20{ }^{\circ}{ }^{\circ}\right.$ this ${ }^{\circ}$ is ${ }^{\circ}$ the only method that can simultaneously facilitate the MS detection of acidic species in complex mixtures and discriminate the acidic groups, sulfate, and phosphate.

\section{Acknowledgments}

The authors acknowledge the National Institutes of Health for funding (project numbers 1 P20 RR17708-01 and RO1GM077266).

\section{References}

1. Petzold, C. J.; Leavell, M. D.; Leary, J. A. Screening and identification of acidic carbohydrates in bovine colostrums by using ion/molecule reactions and Fourier transform ion cyclotron resonance mass spectrometry: Specificity toward phosphorylated complexes. Anal. Chem. 2004, 76, 203-210. 
2. Bossio, R. E.; Marshall, A. G. Baseline resolution of isobaric phosphorylated and sulfated peptides and nucleotides by electrospray ionization FTICR MS: Another step toward mass spectrometry-based proteomics. Anal. Chem. 2002, 74, 16741679.

3. Mann, M.; Ong, S.; Grønborg, M.; Steen, H.; Jensen, O. N.; Pandey, A. Analysis of protein phosphorylation using mass spectrometry: Deciphering the phosphoproteome. Trends Biotechnol. 2002, 20, 261-268.

4. Mclachlin, D.; Chait, B. T. Analysis of phosphorylated proteins and peptides by mass spectrometry. Curr. Opin. Chem. Biol. 2001, 5, 591-602.

5. Nelson, D. L.; Cox, M. M. Biosignaling. In Principles of Biochemistry; W. H. Freeman and Company, Inc: New York, 2004; pp 428-429.

6. Zhou, H.; Watts, J. D.; Aebersold, R. A systematic approach to the analysis of protein phosphorylation. Nat. Biotechnol. 2001, 19, 375-378.

7. Gao, H.; Petzold, C. J.; Leavell, M. D.; Leary, J. A. Investigation of ion/molecule reactions as a quantification method for phosphorylated positional isomers: An FT-ICR approach. J. Am. Soc. Mass Spectrom. 2003, 14, 916-924.

8. Nelson, D. L.; Cox, M. M. Biosignaling. In Principles of Biochemistry; W. H. Freeman and Company, Inc: New York, 2004; pp 421-422.

9. Siegel, M. M.; Tabei, K.; Kagan, M. Z.; Vlahov, I. R.; Hileman, R. E.; Linhardt, R. J. Polysulfated carbohydrates analyzed as ion-paired complexes with basic peptides and proteins using electrospray negative ionization mass spectrometry. J. Mass Spectrom. 1997, 32, 760-772.

10. Witczak, Z. J.; Nieforth, K. A. Carbohydrates as new and old targets for future drug design. In Carbohydrates in drug design; Marcel Dekker, Inc.: New York, 1997; pp 1-39.

11. Delcommenne, M.; Kannagi, R.; Johnson, P. TNF- $\alpha$ increases the carbohydrate sulfation of CD44: Induction of 6-sulfo $\mathrm{N}$-acetyl lactosamine on $\mathrm{N}$ - and O-linked glycans. Glycobiology 2002, 12, 613-622.

12. Bowman, K. G.; Cook, B. N.; de Graffenried, C. L.; Bertozzi, C. R. Biosynthesis of L-selectin ligands: Sulfation of sialyl Lewis x-related oligosaccharides by a family of GlcNAc-6sulfotransferases. Biochemistry 2001, 40, 5382-5391.

13. Green E. D.; Baenziger, J. U. Asparagine-linked oligosaccharides on lutropin, follitropin, and tryrotropin. J. Biol. Chem. 1988, 263, 36-44.

14. Bai, X.; Brown, J. R.; Varki, A.; Esko, J. D. Enhanced 3-Osulfation of galactose in Asn-linked glycans and Maackia amurenesis lectin binding in a new Chinese hamster ovary cell line. Glycobiology 2001, 11, 621-632.

15. Chen, S. L.; Huddleston, M. J.; Shou, W.; Deshaies, R. J.; Annan, R. S.; Carr, S. A. Mass spectrometry-based methods for phosphorylation site mapping of hyperphosphorylated pro- teins applied to Net1, a regulator of exit from mitosis in yeast. Mol. Cell. Proteom. 2002, 1, 186-187.

16. Tuytten, R.; Lemiere, F.; Dongen, W. V.; Esmans, E. L.; Slegers, $\mathrm{H}$. Short capillary ion-pair high performance liquid chromatography coupled to electrospray (tandem) mass spectrometry for the simultaneous analysis of nucleoside mono, di-, and triphosphates. Rapid Commun. Mass Spectrom. 2002, 16, 12051215.

17. Ruse, C. I.; Willard, B.; Jin, J. P.; Hass, T.; Kinter, M.; Bond, M. Quantitative dynamics of site-specific protein phosphorylation determination using liquid chromatography electrospray ionization mass spectrometry. Anal. Chem. 2002, 74, 16581664.

18. Watkins, M. A.; Price, J. M.; Winger, B. E.; Kenttamaa, H. I. Ion-molecule reactions for mass spectrometric identification of functional groups in protonated oxygen-containing monofunctional compounds. Anal. Chem. 2004, 76, 964-976.

19. Juhasz, P.; Biemann, K. Mass spectrometric molecular-weight determination of highly acidic compounds of biological significance via their complexes with basic polypeptides. Proc. Natl. Acad. Sci. U.S.A. 1994, 91, 4333-4337.

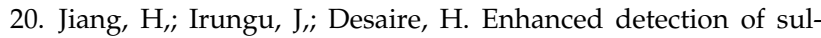
fated glycosylation sites in glycoproteins. J. Am. Soc. Mass Spectrom., in press.

21. Juhasz, P.; Biemann, K. Utility of noncovalent complexes in the matrix-assisted laser desorption ionization mass spectrometry of heparin-derived oligosaccharides. Carbohydr. Res. 1995, 270, 131-147.

22. Fromm, J. R.; Hileman, R. E.; Caldwell, E. E; Weiler, J. M.; Linhardt, R. J. Differences in the interaction of heparin with arginine and lysine and the importance of these basic amino acids in the binding of heparin to acidic fibroblast growth factor. Arch. Biochem. Biophys. 1995, 323, 279-287.

23. Svoboda, M.; Meister, W.; Kitas, E. A.; Vetter, W. The influence of strongly acidic groups on the protonation of peptides in electrospray MS. J. Mass Spectrom. 1997, 32, 1117-1123.

24. Harvey, D. J.; Bousfield, G. R. Differentiation between sulphated and phosphated carbohydrates in low-resolution matrix-assisted laser desorption/ionization mass spectra. Rapid Commun. Mass Spectrom. 2005, 19, 287-288.

25. Desaire, H.; Leary, J. A. The effects of coordination number and ligand size on the gas phase dissociation and Stereochemical differentiation of cobalt-coordinated monosaccharides. Int. J. Mass Spectrom. 2001, 209, 171-184.

26. Desaire, H.; Leavell, M. D.; Leary, J. A. Solvent effects in tandem mass spectrometry: Mechanistic studies indicating how a change in solvent conditions and $\mathrm{pH}$ can dramatically alter CID spectra. J. Org. Chem. 2002, 67, 3693-3699.

27. Chang, R. Acids and Bases. In Chemistry; McGraw-Hill, Inc.: New York, 2005; pp 626-675. 